\title{
Geoelectrical investigation of groundwater potential and vulnerability of Oraifite, Anambra State, Nigeria
}

\author{
Joy O. Eugene-Okorie ${ }^{1}$ - Daniel N. Obiora ${ }^{1}$. Johnson C. lbuot $^{1} \cdot$ Desmond O. Ugbor $^{1}$
}

Received: 1 May 2019 / Accepted: 7 September 2020 / Published online: 25 September 2020

(c) The Author(s) 2020

\begin{abstract}
Electrical resistivity survey employing vertical electrical sounding was carried out in Oraifite, Southeastern Nigeria, involving a total of twenty soundings across, in order to assess the groundwater potential and the aquifer vulnerability in Oraifite. The field data were interpreted using the WINRESIST software, and the resulting geoelectric curves give the resistivities, depths and thicknesses of each geoelectrical layer. Dar Zarrouk parameters and aquifer transmissivity were computed using the values of aquifer resistivity and thickness. From the results, variations of the computed parameters were observed. Aquifer resistivity ranges from 420.1 to $27,585.8 \Omega \mathrm{m}$ having an average value of $4906.3 \Omega \mathrm{m}$, while its thickness varies from 13.4 to $93.9 \mathrm{~m}$. Longitudinal conductance varies from 0.0015 to $0.2136 \Omega^{-1}$, transverse resistance ranges from $29,388.88$ to $1,158,604.0 \Omega \mathrm{m}^{2}$, while the transmissivity varies from 1.1692 to $123.7905 \mathrm{~m}^{2} /$ day. The contour maps reveal the distributions of these parameters, which help in delineating zones with different layer characteristics. The result from this study can be a reference for decision making in the abstraction and management of groundwater repositories.
\end{abstract}

Keywords Vertical electrical sounding $\cdot$ Groundwater potential $\cdot$ Vulnerability $\cdot$ Dar Zarrouk parameters $\cdot$ Aquifer transmissivity · Oraifite

\section{Introduction}

Water is an essential resource for human development. It is used for various purposes which include domestic, industrial and agricultural purposes. Groundwater is an important water resource in both the urban and rural areas of Nigeria. It is accessed mainly in the form of shallow (hand-dug) and deep (boreholes) wells. The quality of groundwater is a major concern to residents, since these boreholes/wells are drilled without prior geophysical information (Ibuot et al. 2017a; Obiora et al. 2016a, b). The development of groundwater resources for potable use has increased drastically over the years due to rapid expansion of cities, increase in population and contamination of surface water. For effective groundwater development, there is a need for adequate knowledge of the properties of subsurface aquifer of the study area, since these properties have great influence on the aquifer repositories. Due to the heterogeneous nature of

Daniel N. Obiora

daniel.obiora@unn.edu.ng

1 Department of Physics and Astronomy, University of Nigeria, Nsukka, Enugu State, Nigeria the subsurface, these properties vary widely across an area of study (Ibuot et al. 2017b; Obiora et al. 2015; Alhassan et al. 2015).

Groundwater is more desirable than surface water because unlike surface water, it is relatively free from contamination and does not require elaborate purification. The awareness of the groundwater potential and vulnerability is important for sustainable development of groundwater resources. A good knowledge of the aquifer hydraulic parameters (transverse resistance, transmissivity, longitudinal conductance, hydraulic conductivity, etc.) is required in order to have a successful exploration, exploitation and management of groundwater (George et al. 2015). The need for groundwater resources rises globally due to an increase in consumption; the groundwater repositories should be protected from surface contaminants. Groundwater contamination resulting from leaching of decomposed waste, septic tanks, pesticide, etc., has caused some boreholes/wells to be deserted (Makeig 1982). This is attributed to wildcat drillings without prior geophysical information about the area, which will serve as guide to drillers (Obiora et al. 2016c).

Groundwater vulnerability is the risk of contaminants used or disposed on or near the ground surface to influence 
groundwater quality (Villumsen and Sonderskov 1982). The key factors that determine the vulnerability of an aquifer system are the permeability, porosity and thickness of the geologic formations above an aquifer (Harter and Walker 2001). Also, groundwater flow affects the spread of these contaminants in the aquifer layers and the flow of groundwater is influenced by factors such as inter-granular pores, fissures and interconnected fractures. Vulnerability is high if the earth materials provide protection to groundwater repositories from surface contaminants, while vulnerability will be low if the natural factors provide relatively good protection from surface contaminants. For effective protection of aquifer repositories, it is necessary to take into consideration all pollutant sources in order to ensure sustainable groundwater management strategy. In the study area, pit toilets and dumpsites are sited indiscriminately without taking into consideration the hydrogeological settings of the area, in so doing rendering the future of groundwater at risk. The use of chemical products, such as pesticides and herbicides in farms, posed threat to groundwater repositories in the study area. These contaminants pose a serious threat to the health of the people in the area. The study is aimed at assessing groundwater potential and aquifer protective capacity of the study area estimated from the Dar Zarrouk parameters.

\section{Location and geology of the study area}

Oraifite is located in Ekwusigo Local Government Area of Anambra state, southeastern Nigeria. It lies within latitude $5.98^{\circ}-6.03^{\circ} \mathrm{N}$ and longitude $6.80^{\circ}-6.85^{\circ} \mathrm{E}$ (Fig. 1a). It is bounded on the east by Nnewi, on the west by the creeks of the River Niger and Atani, on the north by Ichi, Ojoto, Oba and Akwukwu, and on the south by Ozubulu. The study area is located in the tropical wet climate zone and experience two seasons: rainy season (April-September) and dry season (October-March). The mean annual rainfall is about $2000 \mathrm{~mm}$ with maximum monthly rainfall during the peaks, ranging from 270 to $360 \mathrm{~mm}$ (Ekenta et al. 2015). The mean temperature of the region varies between 27 and $38^{\circ} \mathrm{C}$ that most times has a peak value of $35^{\circ} \mathrm{C}$ between January and April (Odumodu and Ekenta 2012). The study area is dominated by the Ogwashi-Asaba Formation (Fig. 1b), which is identified within the Palaeogene Anambra Basin. The Ogwashi-Asaba Formation recently known as Ogwashi Formation was originally referred to as a lignite group (Wilson 1925; Wilson and Bain 1928), lignite series (Simpson, 1949) and lignite formation (De Swardt and Casey 1963). Reyment (1965) suggested an Oligocene-Miocene age for the Ogwashi-Asaba Formation, but palynological results by the works of Jan du Chene et al. (1978) proposed a late Eocene age for the base part. The Ogwashi-Asaba Formation is widely characterized by varying lithologies which are composed of alternation of clays, sands, sandstones, shale, grits and lignites (Kogbe 1976). The brownish to black lignite seams found within the Ogwashi-Asaba Formation vary in thickness a few millimeters to a maximum of about $6 \mathrm{~m}$, while the sandstone units have colors usually yellowish, whitish, reddish to reddish brown.

\section{Data Acquisition and Interpretation}

The geophysical field survey was executed using the IGIS resistivity meter model SSR-MP-ATS with its accessories, and coordinates and elevations were determined using the Global Positioning System (GPS). Twenty vertical electrical soundings (VES) involving Schlumberger configuration were carried out with half-current electrode spread of $300 \mathrm{~m}$ and half-potential electrode spread of $10 \mathrm{~m}$. The measured data were converted to apparent resistivity $\left(\rho_{a}\right)$ using Eq. 1:

$\rho_{a}=G R_{a}$

where $R_{a}$ is the apparent resistance and $G$ is the geometric factor given by Eq. 2;

$G=\pi\left[\frac{\left(\frac{A B}{2}\right)^{2}-\left(\frac{M N}{2}\right)^{2}}{M N}\right]$.

$\mathrm{AB}$ and $\mathrm{MN}$ are the distances between the current electrodes and the potential electrodes, respectively.

The processing and interpretation of the field data were accomplished in three stages. The first stage involves plotting of the vertical electrical sounding curves for each of the survey locations from the calculated apparent resistivity and half-current electrode spacing (Fig. 2a and b). The second stage involves smoothing and analyzing the VES profiles in terms of their various layers of actual resistivity. The third stage involves the use of resistivity interpretation software called the WINRESIST to quantitatively interpret the data. This is a direct interpretation approach, which generates quantitatively the parameters of the resistivity, depth and thickness of the subsurface. The longitudinal conductance (S) and transverse resistance (T) referred to as the Dar Zarrouk parameters are important parameters in electrical prospecting that explained the problem of non-uniqueness in the interpretation of resistivity depth sounding curves (Maillet 1947; Henriet 1976). The transverse resistance and longitudinal conductance were determined using Eqs. 3 and 4:

$T=h \rho$

and

$S=\frac{h}{\rho}$ 
Fig. 1 a Map of Anambra showing the location of the Oraifite. b Geologic map of Oraifite with geologic cross section

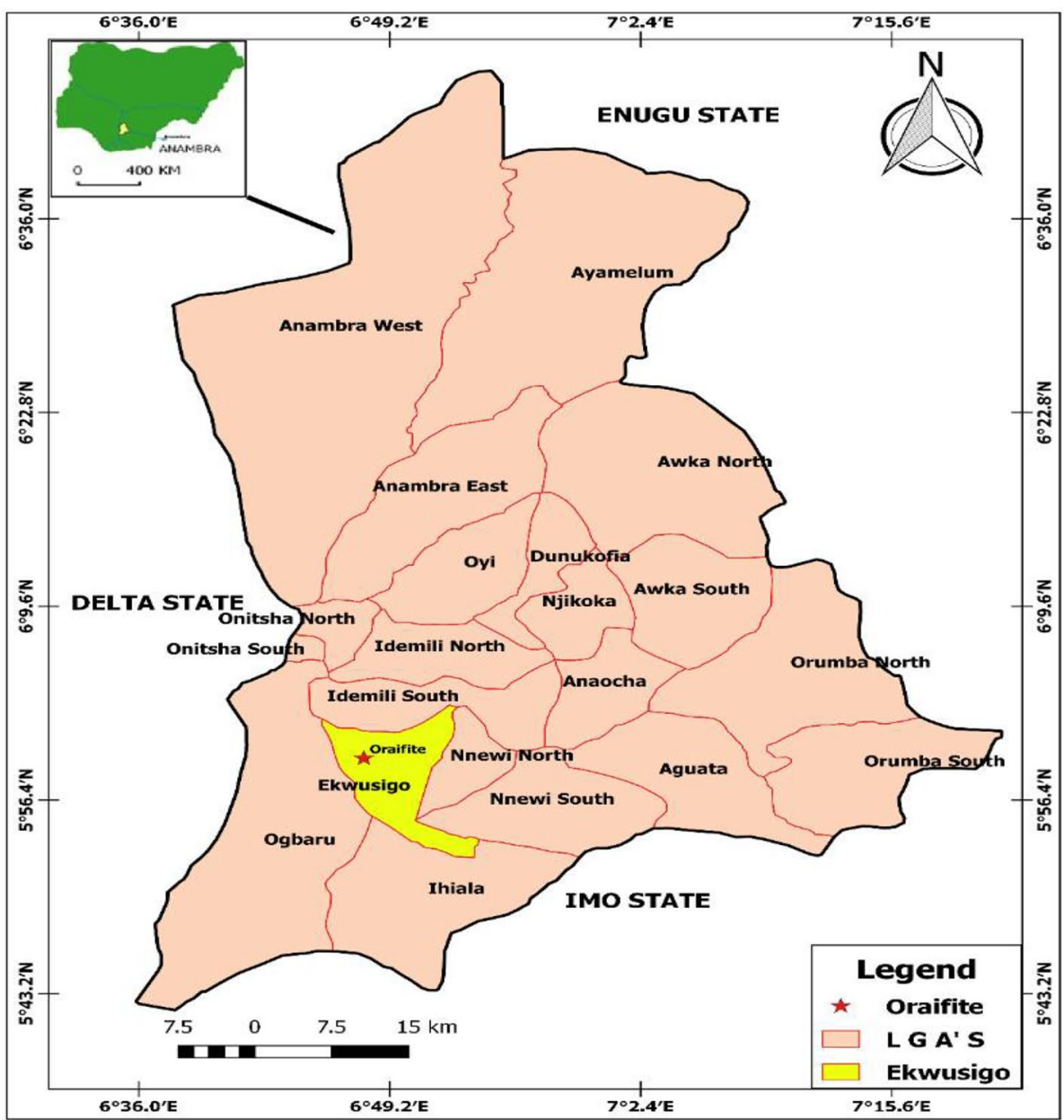

a Map of Anambra showing the location of the Oraifite

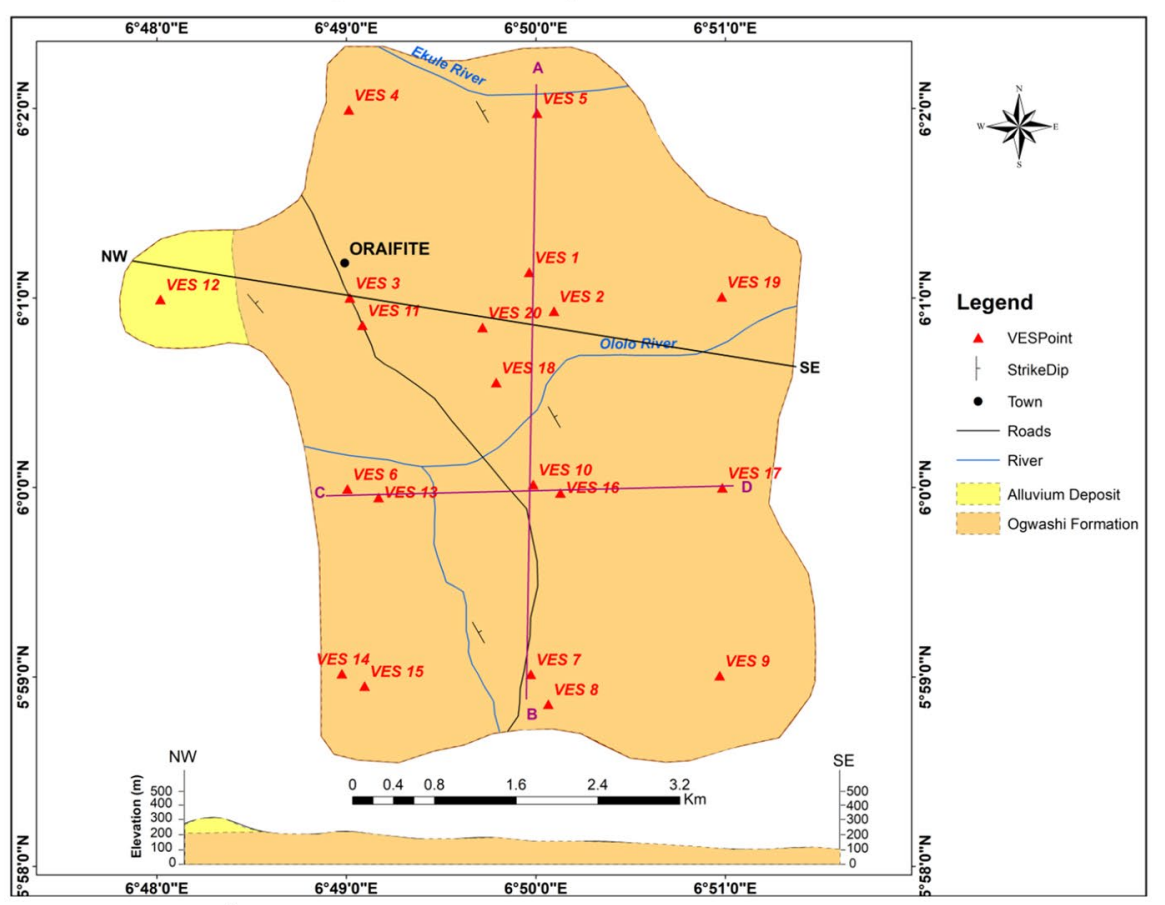

b Geologic map of Oraifite with geologic cross-section 
Fig. 2 a Geoelectric curve model for VES 2. b Geoelectric curve model for VES 8

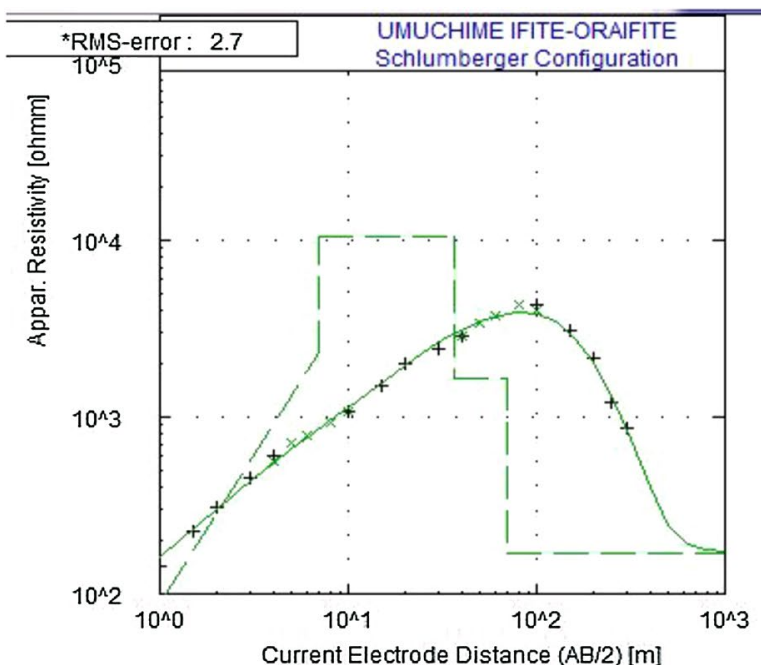

\begin{tabular}{|lllll} 
No & Res & Thick & Depth \\
\hline 1 & 89.5 & 0.5 & 0.5 \\
2 & 2322.6 & 6.4 & 6.9 \\
3 & 10367.6 & 29.4 & 36.4 \\
4 & 1670.9 & 34.0 & 70.3 \\
5 & 168.8 & --- & --
\end{tabular}

a Geoelectric curve model for VES 2

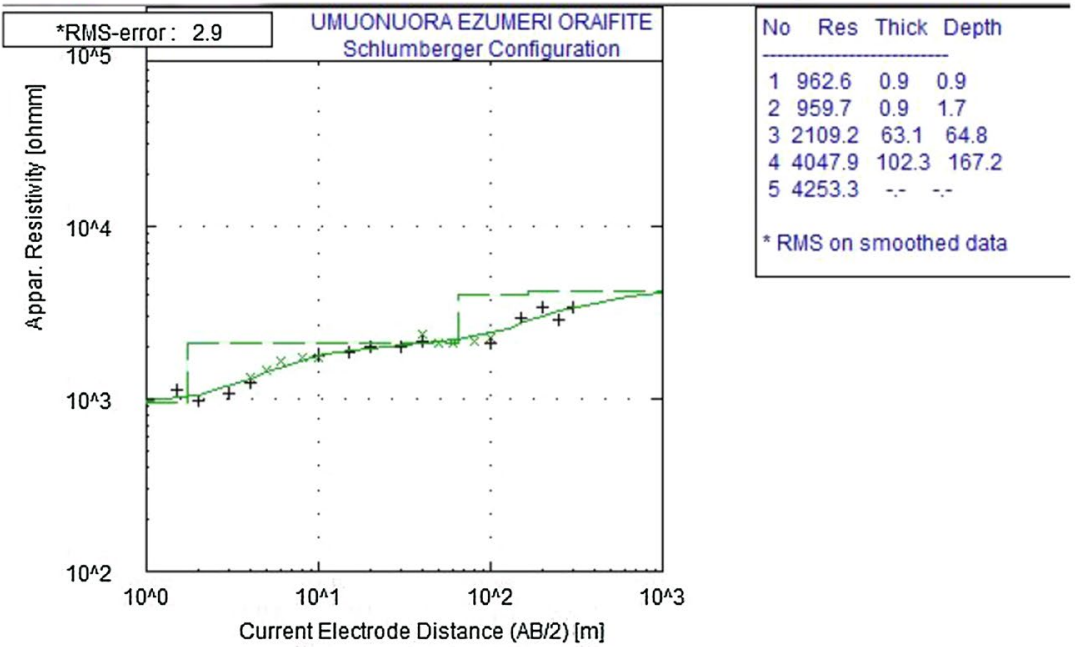

b Geoelectric curve model for VES 8 where $h$ and $\rho$ are layer thickness and resistivity, respectively.

The flow of groundwater through aquifer units is influenced by transmissivity, which indicates the ability of a layer to transmit fluids through its entire thickness. It is related to hydraulic conductivity and thickness by Eq. 5 (Niwas and Singhal 1981):

$T_{r}=K h$

where $T_{r}$ is the transmissivity and $K$ is the hydraulic conductivity.

\section{Results and discussion}

The analysis and interpretation of the resistivity data are presented in Table 1 . It reveals that the area is characterized by 4 to 6 geoelectric subsurface layers with a 5-layer curve type as dominant. The study area is characterized by the following curve types: AK, AA and KQ (VES 10, 11, 12, 16, 17 and 20), AKH, KHK, HAK, QQQ, HAA, AAA and AKQ (VES 1, 2, 3, 4, 5, 6, 8, 13, 14, 15, 18 and 19) and AAKQ and AKQQ (VES 7 and 9). Figure $3 a$ and $b$ is the geoelectric sections constraint with a borehole lithologic log showing the variations of resistivities with depths and the geologic sediments. The geoelectric sections transect AB (VES 5, 1 and 7) and transect CD (VES 6, 13, 10, 16 and 17). The numbers within the profiles indicate the values of resistivity in Ohm-m at various depths. The resistivity of the first layer has values ranging from 89.5 to $4083.8 \Omega \mathrm{m}$, while the thickness and depth range from 0.5 to $3.6 \mathrm{~m}$ and 0.5 to $3.6 \mathrm{~m}$, respectively. The resistivity values of the second layer range from 339.3 to $9779.3 \Omega \mathrm{m}$, with a thickness range of 0.9 to $34.4 \mathrm{~m}$ and a depth range of 1.7 and $37.9 \mathrm{~m}$. The third layer has a resistivity range of 1159.8 to $34,888.9 \Omega \mathrm{m}$, with 


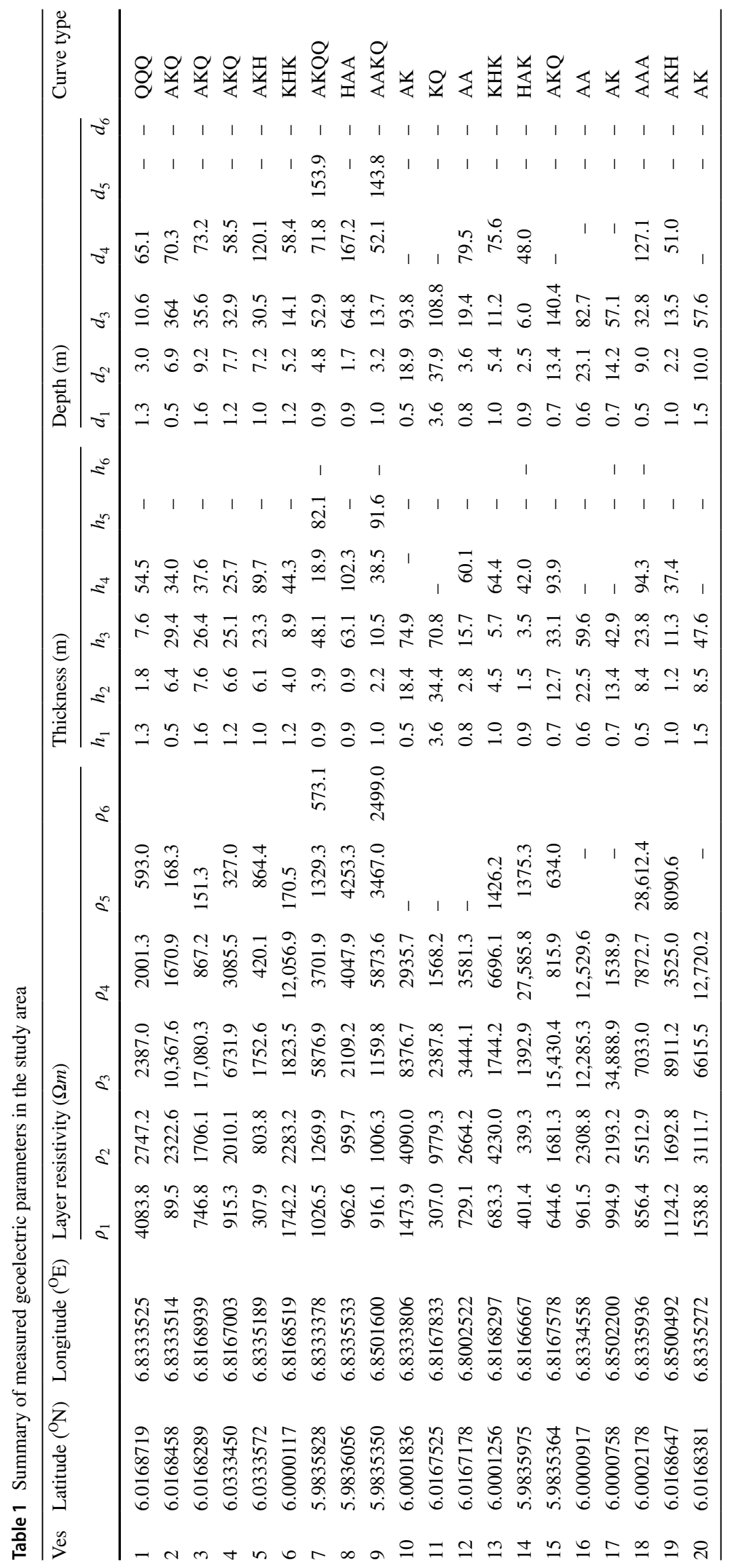




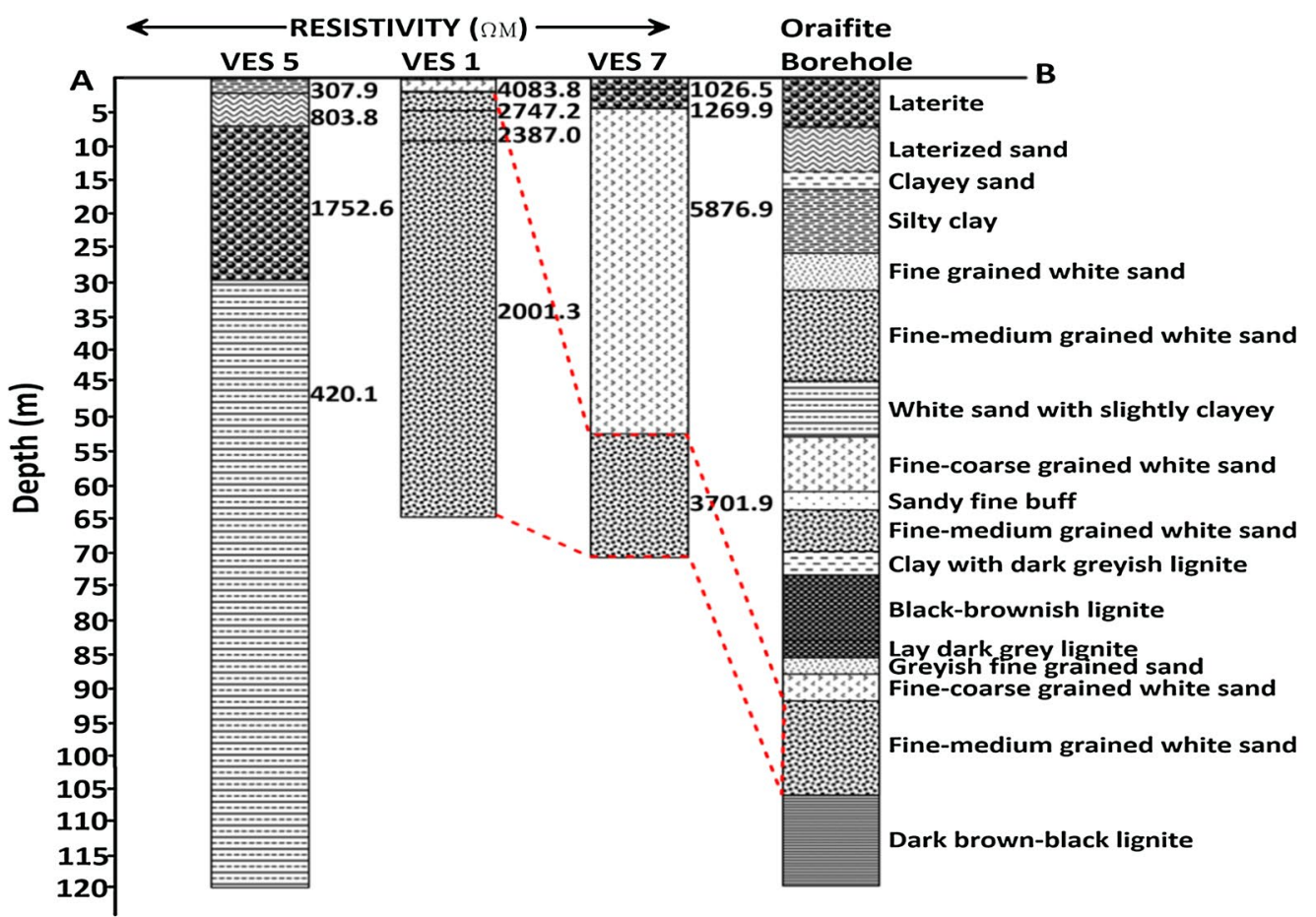

a Geoelectric section along transect $\mathrm{AB}$

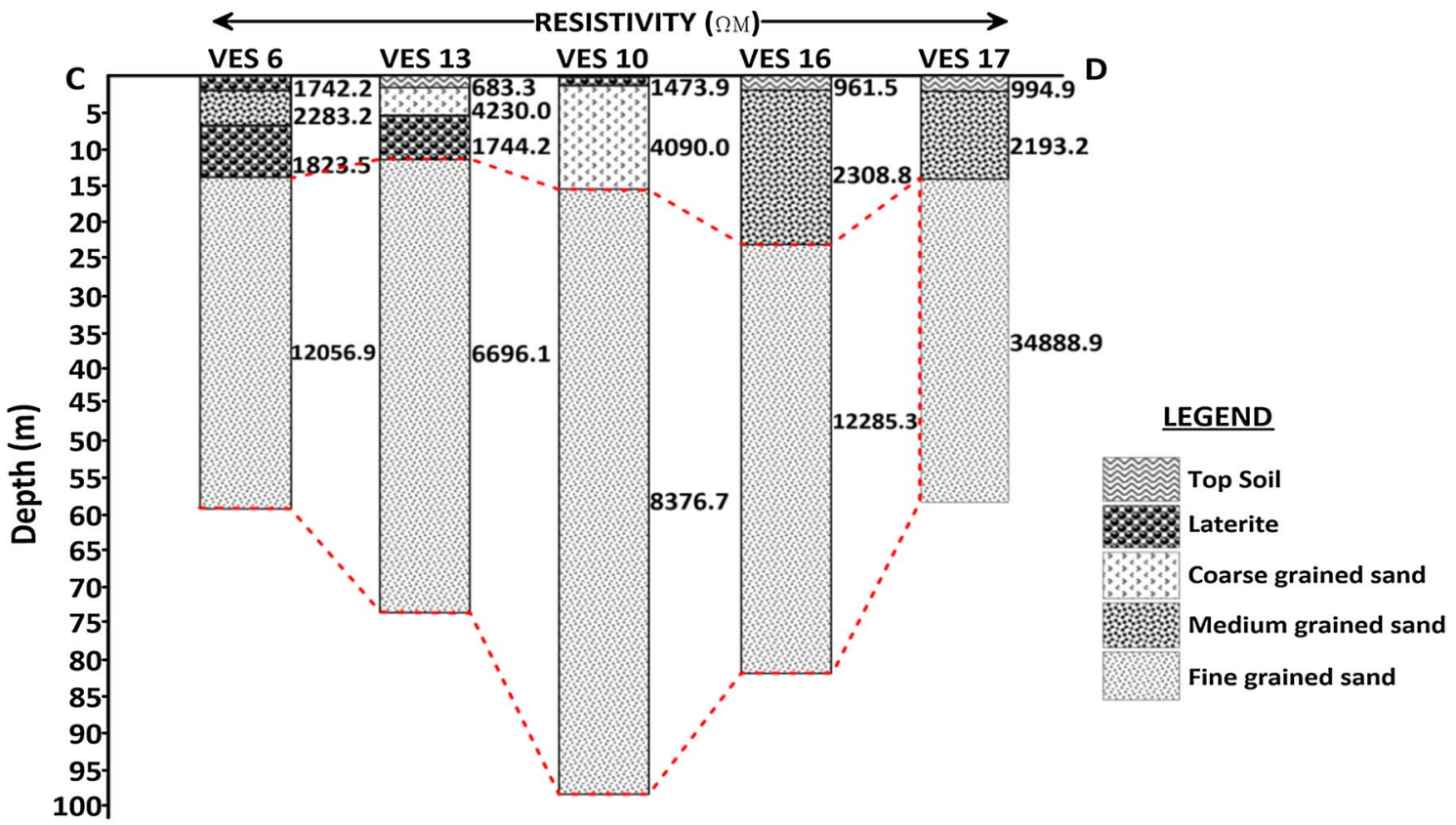

b Geoelectric section along transect CD

Fig. 3 a Geoelectric section along transect $A B$. b Geoelectric section along transect CD

a thickness range of 3.5 to $74.9 \mathrm{~m}$ and a depth range of 6.0 to $140.4 \mathrm{~m}$. The fourth layer resistivity ranges from 420.1 to $27,585.8 \Omega \mathrm{m}$ with a thickness range of 18.9 to $102.3 \mathrm{~m}$ and a range of 48.0 to $167.2 \mathrm{~m}$ for the depth with thickness and depth undefined in some VES points. The fifth layer has a resistivity range of 151.3 to $28,612.4 \Omega \mathrm{m}$, with a thickness range of 82.1 to $91.6 \mathrm{~m}$ and depth range of 143.8 to $153.9 \mathrm{~m}$. The sixth layer with resistivity values of $573.1 \Omega \mathrm{m}$ and $2499.0 \Omega \mathrm{m}$ was observed at VES 7 and 9, respectively, with infinite thickness and depth. 
The values of the aquifer resistivity $\left(\rho_{\mathrm{a}}\right)$ and thickness $\left(h_{\mathrm{a}}\right)$ were used to estimate the Dar Zarrouk parameters and the aquifer transmissivity (Table 2).

The resistivity contour map (Fig. 4) shows the variation of aquifer resistivity in the study area. The contour map shows high resistivity in the western part of the study area and decreases across the study area toward the northern part. This suggests that zones with low resistivity may be due to high conductive geomaterials, as such may reduce the groundwater quality. These low resistivity values may also be due to the presence of groundwater in the sediments such as sands and sandstones (Alile et al. 2011). The high aquifer resistivity in VES 14 compared to other VES points may be attributed to the compact nature of the subsurface geologic materials present in the subsurface location. Obiajulu and Okpoko (2015) who investigated groundwater potential in Ihiala with similar geologic terrain as Oraifite obtained aquifer resistivity values ranging from 153 to $24,691 \Omega \mathrm{m}$. The distribution of aquifer thickness (Fig. 5) shows a relative increase across the study area from southeast to northwest. The relatively high aquifer thickness value observed in the study area makes it productive and desirable. This agrees with the results of Anizoba et al. (2015a) and Chinwuko et al. (2016) whose results delineated thick and prolific aquifer layers in parts of Anambra State.

The values of the longitudinal conductance were used in rating the aquifer protective capacity of the area. The values of longitudinal conductance are used because the earth acts as a natural filter to the percolating fluid. The earth's ability to allow fluids to infiltrate into the subsurface depends on the thickness, the covering materials and the protective ability of the aquifer (Harter and Walker 2001). Silts and clays are suitable geomaterials that provide good aquifer protective covers. This may be attributed to the grain distribution of clay and shale. The estimated longitudinal conductance values (Table 2) range from 0.0015 to $0.2135 \Omega^{-1}$, and the estimated values were compared with the protective capacity rating according to Henriet (Henriet 1976) and Oladapo et al.(2004). The study area is generally dominated by poor protective capacity rating $(<0.1)$ except at VES 15 which is observed to be weak $\left(0.115088 \Omega^{-1}\right)$ and VES 5 rated as moderate $\left(0.213521 \Omega^{-1}\right)$. The areas with weak and poor protective capacity rating are most likely prone to contamination. This indicates high permeability of the layers.

The longitudinal conductance contour map (Fig. 6) shows an increase toward the north, with the highest protective capacity rating observed in the extreme northwest. This coincides with region having high aquifer resistivity (low conductivity) and thickness. It can be inferred that the low permeability in the northwest may be due to the relatively thick aquifer layer. These areas having weak and poor aquifer protective capacity are vulnerable to surface contaminants which may be from leakage of septic tanks, pit toilets, refuse dump, improper use and disposal of pesticides and
Table 2 Aquifer parameters of the location

\begin{tabular}{|c|c|c|c|c|c|c|c|}
\hline VES & $\begin{array}{l}\text { Latitude } \\
\left({ }^{\mathrm{O}} \mathrm{N}\right)\end{array}$ & Longitude $\left({ }^{\mathrm{O}} \mathrm{E}\right)$ & $\rho_{\mathrm{a}}(\Omega \mathrm{m})$ & $h_{\mathrm{a}}(\mathrm{m})$ & $S\left(\Omega^{-1}\right)$ & $T\left(\Omega \mathrm{m}^{2}\right)$ & $T_{\mathrm{r}}\left(\mathrm{m}^{2} /\right.$ day $)$ \\
\hline 1 & 6.0168719 & 6.8333525 & 2001.3 & 54.5 & 0.027232 & $109,070.9$ & 17.5340 \\
\hline 2 & 6.0168458 & 6.8333514 & 1670.9 & 34 & 0.020348 & $56,810.6$ & 12.9434 \\
\hline 3 & 6.0168289 & 6.8168939 & 867.2 & 37.6 & 0.043358 & $32,606.72$ & 26.3912 \\
\hline 4 & 6.0333450 & 6.8167003 & 3085.5 & 25.7 & 0.008329 & $79,297.35$ & 5.52106 \\
\hline 5 & 6.0333572 & 6.8335189 & 420.1 & 89.7 & 0.213521 & $37,682.97$ & 123.7905 \\
\hline 6 & 6.0000117 & 6.8168519 & $12,056.9$ & 44.3 & 0.003674 & $534,120.7$ & 2.6689 \\
\hline 7 & 5.9835828 & 6.8333378 & 1329.3 & 82.1 & 0.061762 & $109,135.5$ & 38.6875 \\
\hline 8 & 5.9836056 & 6.8335533 & 2109.2 & 63.1 & 0.029917 & $133,090.5$ & 19.3299 \\
\hline 9 & 5.9835350 & 6.8501600 & 3467 & 91.6 & 0.026421 & $317,577.2$ & 17.6505 \\
\hline 10 & 6.0001836 & 6.8333806 & 8376.7 & 74.9 & 0.008941 & $627,414.8$ & 6.33823 \\
\hline 11 & 6.0167525 & 6.8167833 & 2387.8 & 70.8 & 0.029651 & $169,056.2$ & 19.3185 \\
\hline 12 & 6.0167178 & 6.8002522 & 3581.3 & 60.1 & 0.016782 & $215,236.1$ & 11.2355 \\
\hline 13 & 6.0001256 & 6.8168297 & 6696.1 & 64.4 & 0.009618 & $431,228.8$ & 6.71555 \\
\hline 14 & 5.9835975 & 6.8166667 & $27,585.8$ & 42 & 0.001523 & $1,158,604$ & 1.16918 \\
\hline 15 & 5.9835364 & 6.8167578 & 815.9 & 93.9 & 0.115088 & $76,613.01$ & 69.7655 \\
\hline 16 & 6.0000917 & 6.8334558 & 2308.8 & 22.5 & 0.009745 & $51,948.00$ & 6.3350 \\
\hline 17 & 6.0000758 & 6.8502200 & 2193.2 & 13.4 & 0.006110 & $29,388.88$ & 3.9580 \\
\hline 18 & 6.8335936 & 6.0002178 & 7033 & 23.8 & 0.003384 & $167,385.4$ & 2.3707 \\
\hline 19 & 6.0168647 & 6.8500492 & 3238.2 & 37.4 & 0.010610 & $131,835.0$ & 7.0959 \\
\hline 20 & 6.0168381 & 6.8335272 & 6615.5 & 47.6 & 0.007195 & $314,897.8$ & 5.0200 \\
\hline AVERAGE & & & 4906.3 & 53.6 & 0.03266 & $239,150.00$ & 20.1919 \\
\hline
\end{tabular}




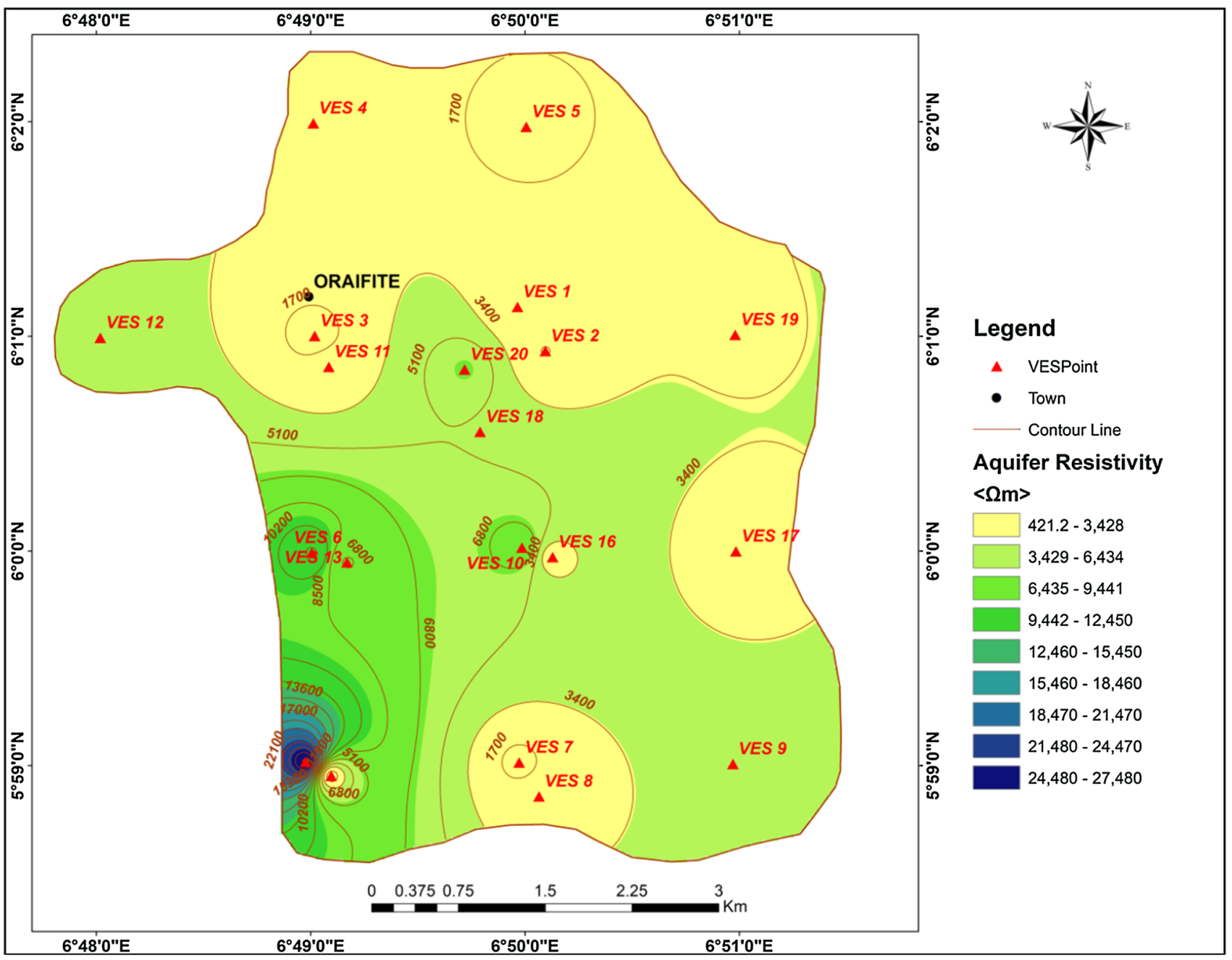

Fig. 4 Contour map of aquifer resistivity showing its distribution in the study area

herbicides used in farms and petroleum storage tanks used in petrol stations. The moderate aquifer protective capacity zones have a higher lessening property on contaminated fluids so that in the face of contamination, such zones are safe.

The transverse resistance values from the VES results range from $29,388.88$ to $1,158,604.0 \Omega \mathrm{m}^{2}$ with an average value of $239,150.0 \Omega \mathrm{m}^{2}$. VES17 is observed to have the lowest transverse resistance value, while VES14 has the highest transverse resistance value. The transverse resistance contour map (Fig. 7) shows the variation of this parameter, which is high in the western part and decreases across toward the northern part having the minimum transverse resistance value. The values of transverse resistance in this study are higher than that obtained by Anizoba et al. (2015b) in Awka, Anambra State.

The transmissivity values (Table 2 ) estimated from the VES results range from 1.1692 to $123.7905 \mathrm{~m}^{2} /$ day, with an average value of $20.1919 \mathrm{~m}^{2} /$ day. The transmissivity values observed in this study are on the average within the range of transmissivity values obtained by Nfor et al. (2007) who worked in some parts of Anambra state. From the result, VES 14 has the lowest transmissivity value indicating low water bearing potential. VES 5 has the highest transmissivity value, indicating that the location has a high water bearing potential and is highly permeable to fluid movement. Using the classification of Offodile (1983), it was observed that VES 6, 14, 17, 18 and 20 have very low groundwater potential, VES 1, 2, 3, 4, 7, 8, 9, 10, 11, 12, 13,16 and 19 have low groundwater potential, while VES 5 and 15 have a moderate groundwater potential. The contour map (Fig. 8) shows that transmissivity varies across the study area. The highest transmissivity is observed in the northwest and decreases down the south across the western part. The part of the study area with high aquifer transmissivity may have more transmissible pore channels. The weighted overlay contour map is shown in Fig. 9 where the highest values are observed in the western zone. 


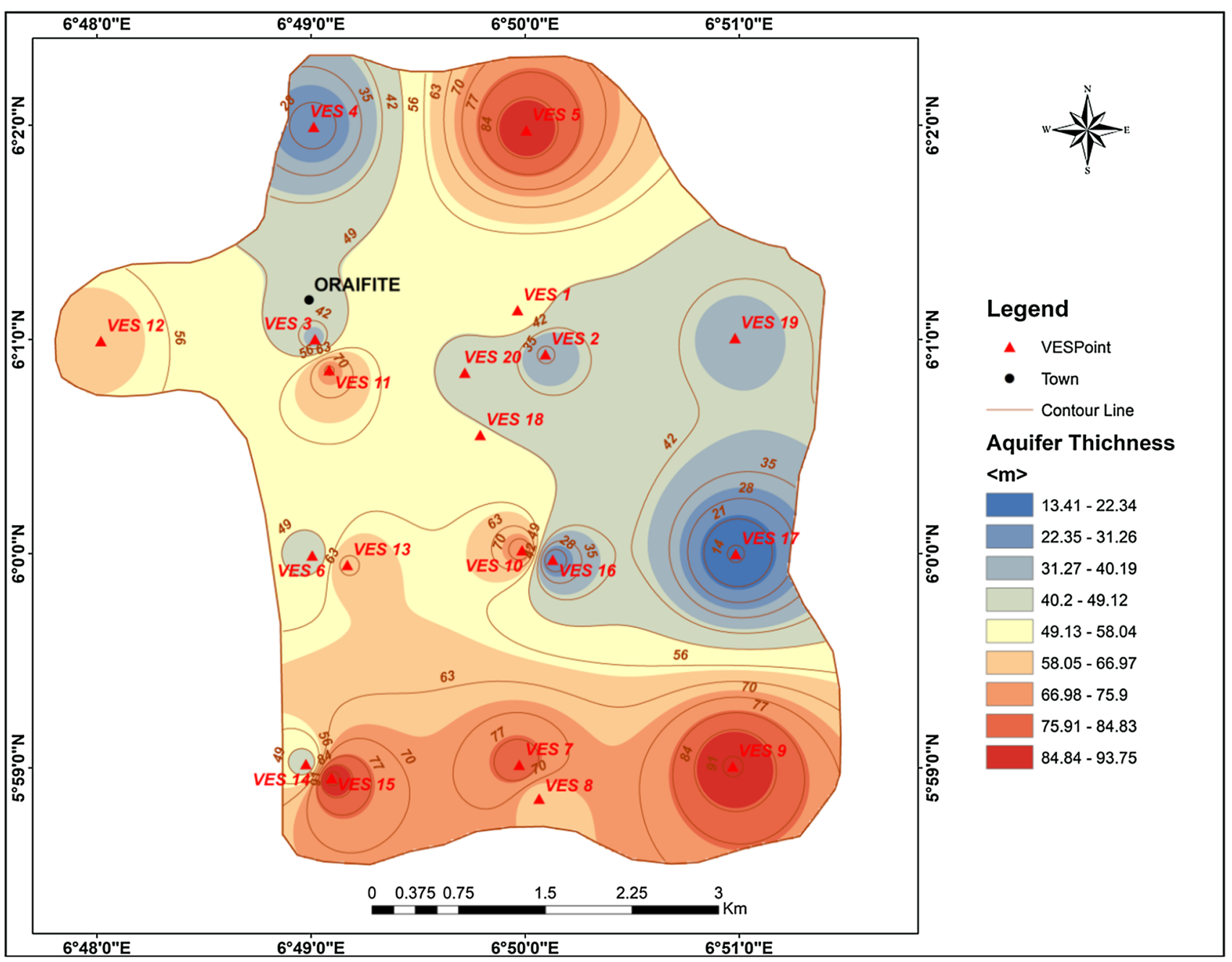

Fig. 5 Contour map of aquifer thickness distribution in the study area

\section{Conclusion}

Twenty VES were carried out to determine the subsurface layer parameters (resistivities, depths and thicknesses) employed in delineating the groundwater potential and vulnerability of Oraifite. The survey involves Schlumberger electrode configuration within the maximum halfpotential electrode spacing of $10 \mathrm{~m}$ and a maximum halfcurrent electrode spacing of $300 \mathrm{~m}$. Four to six geoelectric layers were identified as AK, AA, KQ, AKH, KHK, HAK, QQQ, HAA, AAA, AKQ, AAKQ and AKQQ. The interpreted geoelectric data displayed the variation of aquifer parameters and that of the Dar Zarrouk parameters. The estimated longitudinal conductance values from the VES results range from 0.0015 to $0.2135 \Omega^{-1}$ with an average value of $0.0327 \Omega^{-1}$, transverse resistance values range from $29,388.88$ to $1,158,604.0 \Omega \mathrm{m}^{2}$ with an average value of $239,150.0 \Omega \mathrm{m}^{2}$, and transmissivity has values ranging between 1.1691 and $123.7905 \mathrm{~m}^{2} /$ day, with an average value of $20.1919 \mathrm{~m}^{2} /$ day. It was delineated from the study that $70 \%$ of the study area falls within the low water bearing potential, while $20 \%$ and $10 \%$ were very low and moderate, respectively. It can be said that the groundwater potential of the area is generally low. The study revealed that $90 \%$ of the study area has poor aquifer protective capacity. Therefore, these areas are vulnerable to contamination from infiltration of surface contaminants. 


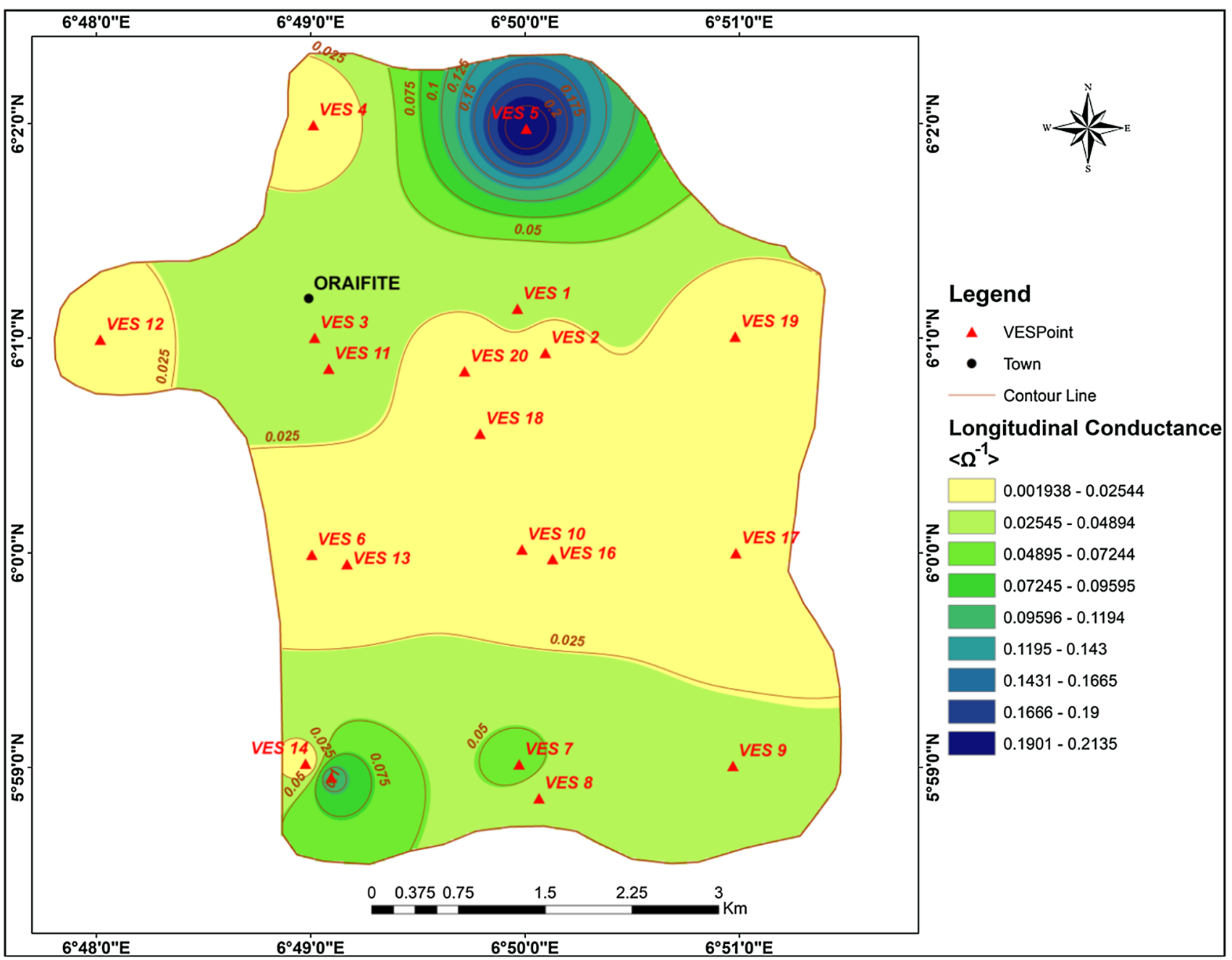

Fig. 6 Contour map of longitudinal conductance showing its distribution in the study area 


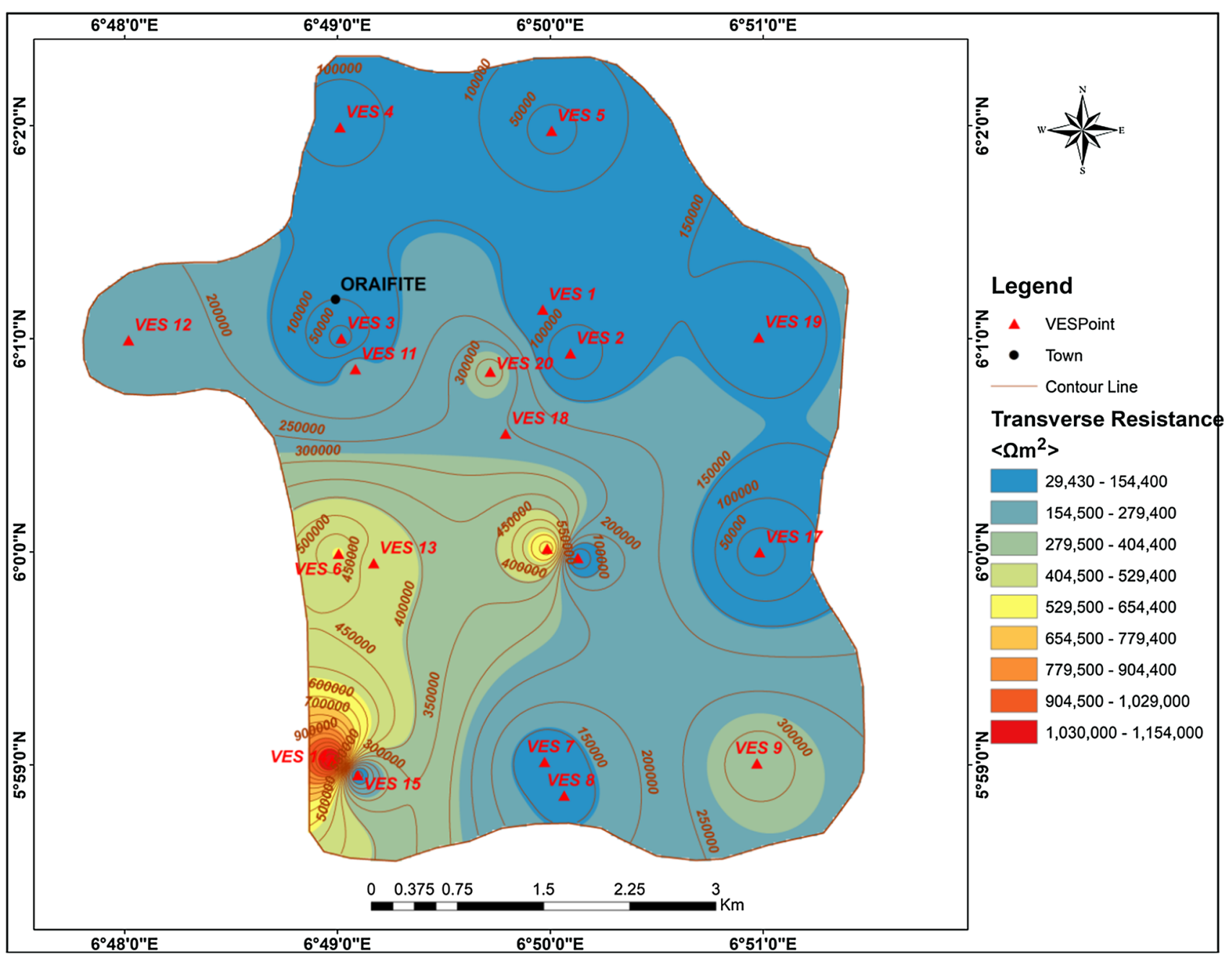

Fig. 7 Contour map of transverse resistance showing its distribution in the study area 


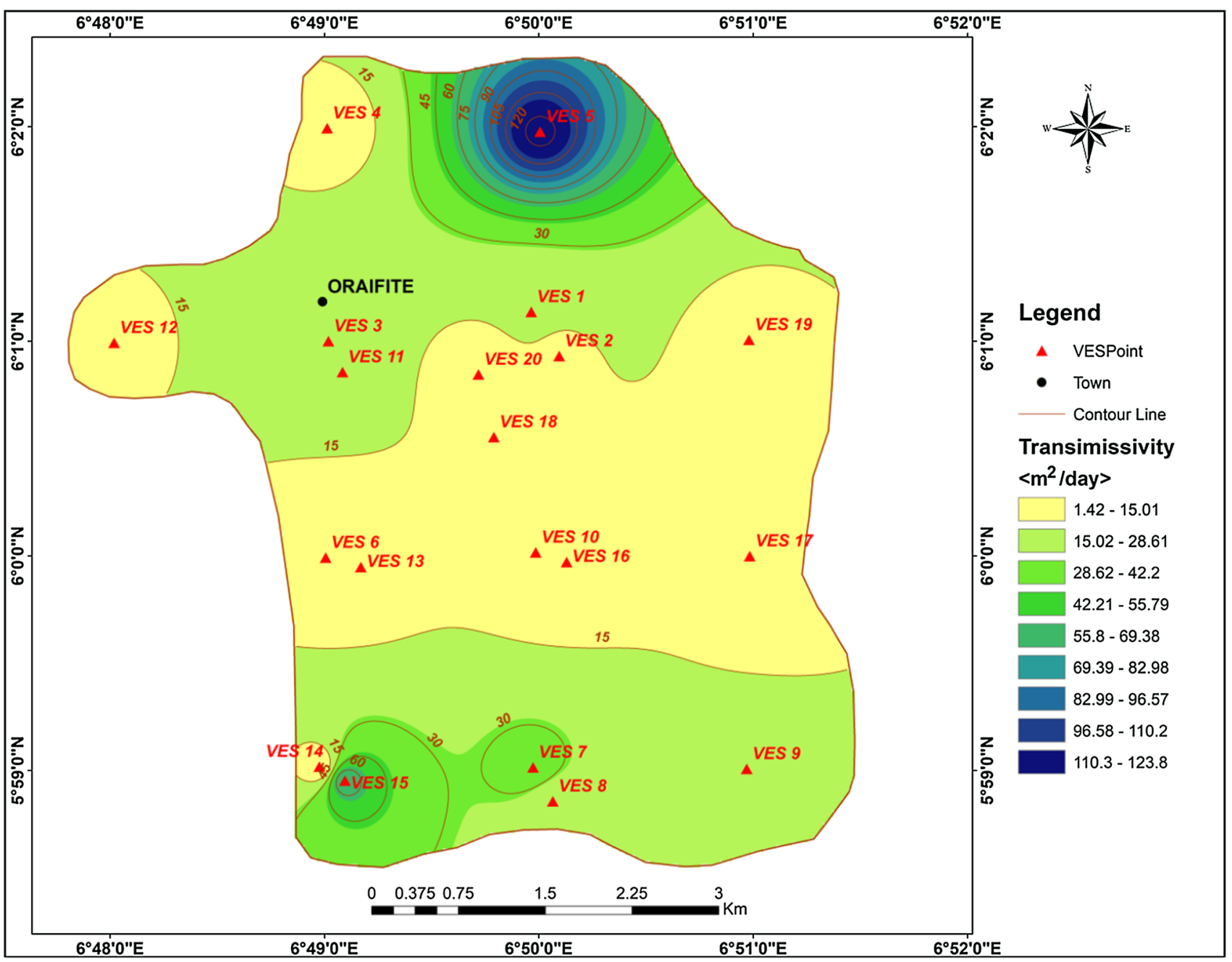

Fig. 8 Contour map showing the variation of transmissivity in the study area 


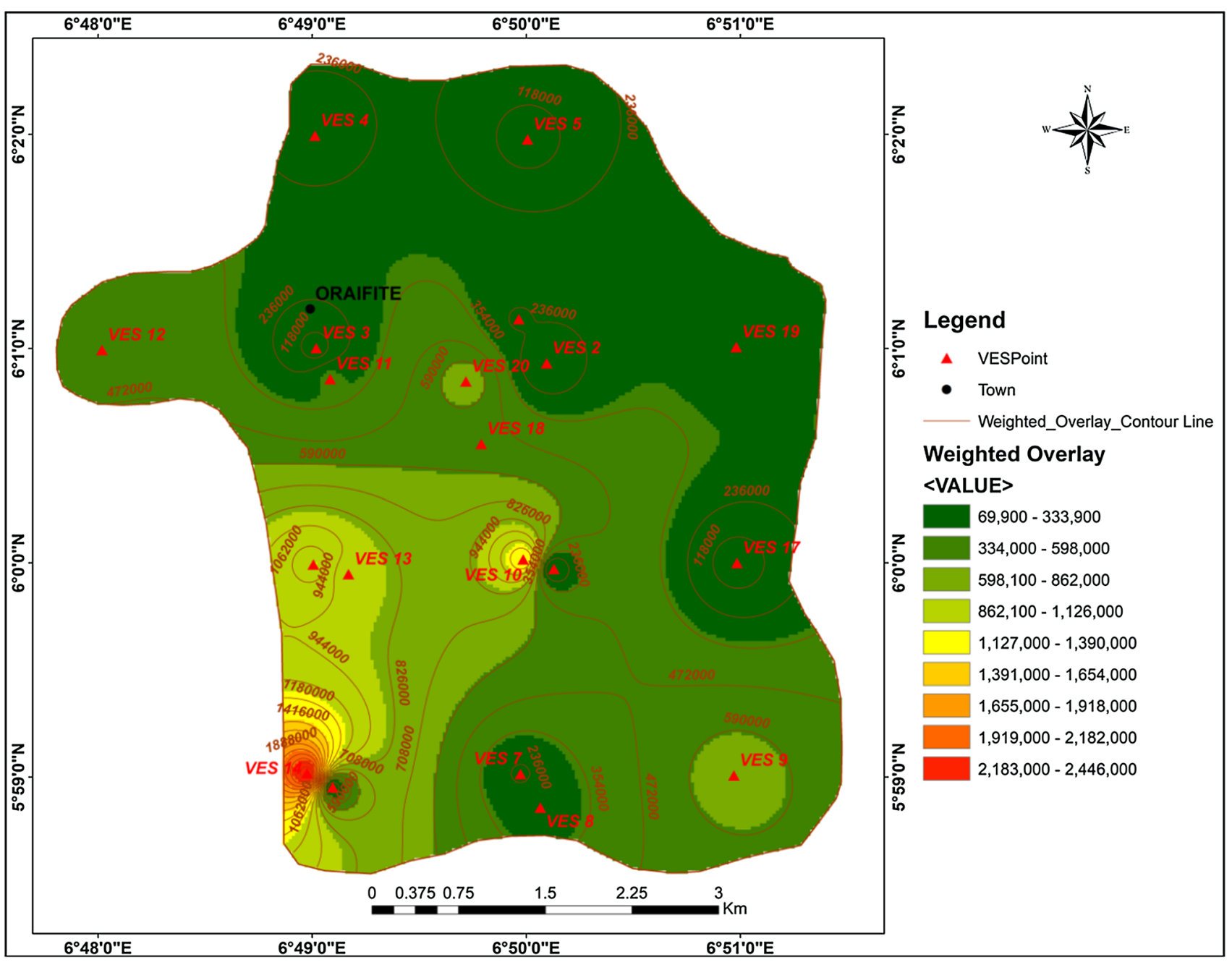

Fig. 9 Weighted overlay contour map

Funding The authors funded the research work.

\section{Compliance with ethical standards}

Conflict of interest The authors declare that they have no conflict of interest.

Human and animal rights This research did not involve human participants and/or animals.

Open Access This article is licensed under a Creative Commons Attribution 4.0 International License, which permits use, sharing, adaptation, distribution and reproduction in any medium or format, as long as you give appropriate credit to the original author(s) and the source, provide a link to the Creative Commons licence, and indicate if changes were made. The images or other third party material in this article are included in the article's Creative Commons licence, unless indicated otherwise in a credit line to the material. If material is not included in the article's Creative Commons licence and your intended use is not permitted by statutory regulation or exceeds the permitted use, you will need to obtain permission directly from the copyright holder. To view a copy of this licence, visit http://creativecommons.org/licenses/by/4.0/.

\section{References}

Alile OM, Ujuanbi O, Evbuomwan IA (2011) Geoelectric investigation of groundwater in Obaretin Iyanomon Locality, Edo State. Nigeria J Geol Min 3(1):13-20

Alhassan DU, Obiora DN, Okeke FN (2015) The assessment of aquifer potentials and aquifer vulnerability of southern Paiko, northcentral Nigeria, using geoelectric method. Global J Pure Appl Sci 21:51-70

Anizoba D, Orakwe L, Chukwuma E, Nwoke O (2015a) Delineation of potential groundwater zones using geoelectrical sounding data at Awka in Anambra State, South-eastern Nigeria. Euro J Biotechnol Biosci 3(1):1-5

Anizoba DC, Chukwuma GO, Chukwuma EC, Chinwuko EC (2015b) Determination of aquifer characteristics from geo-electrical sounding data in parts of Anambra State, Nigeria. Int J Innovat Appl Stud 11(4):832-843

Chinwuko AI, Anakwuba EK, Okeke HC, Onyekwelu CU, Usman AO, Osele CE, Iheme OK (2016) Assessment of hydrogeophysical and geotechnical properties in central part of Anambra State, Nigeria. Int J Geophys Geochem 3(2):6-13

De Swardt AM, Casey OP (1963) The Coal Resources of Nigeria. Bulletin of Geological Survey of Nigeria, 28 
Ekenta OE, Okoro BU, Ezeabasili AC (2015) Hydrogeological characteristics and groundwater quality analysis for selected boreholes in ogbaru local government area, Anambra State, Nigeria. Am Sci Res J Eng Technol Sci 14(2):198-210

George NJ, Ibuot JC, Obiora DN (2015) Geoelectrohydraulic parameters of shallow sandy aquifer in Itu, Akwa Ibom State (Nigeria) using geoelectric and hydrogeological measurements. J Afr Earth Sci 110:52-63

Harter T, Walker LG (2001) Assessing vulnerability of groundwater, 3. Retrieved 30/8/2018 from https://www.dhs.ca.gov/ps/ddwem /dwsap/DWSAPindex.html

Henriet J (1976) Direct applications of the dar zarrouk parameters in groundwater surveys. Geophys Prospect 24(2):344-353

Ibuot JC, Okeke FN, George NJ, Obiora DN (2017a) Geophysical and physicochemical characterization of organic waste contamination of hydrolithofacies in the coastal dumpsite of Akwa Ibom State, southern Nigeria. Water Sci Technol Water supply 17(6):1626-1637

Ibuot JC, Obiora DN, Ekpa MMM, Okoroh DO (2017b) Geoelectrohydraulic investigation of the surficial aquifer unit sand corrosivity in parts of Uyo L. G. A., Akwa Ibom State. Southern Nigeria Appl Water Sci 7:4705-4713

Jan du Chene R, Onyike MS, Sowumi MA (1978) Some new eocene pollen of the ogwashi-asaba formation, southeastern nigeria. Rev Española de Micropaleontol 10:285-322

Kogbe CA (1976) Geology of Nigeria. Elizabethan Publishers, NGR

Maillet R (1947) The fundamental equations of electrical prospecting. Geophysics 12(4):529-556

Makeig KS (1982) National buffers for sludge leachate stabilization of groundwater. Geophysics 20(4):420-429

Nfor BN, Sb O, Ogala JEJ (2007) Extent and distribution of groundwater resources in parts of Anambra State Southeastern Nigeria. J Appl Sci Environ Manage 11(2):215-221

Niwas S, Singhal DC (1981) Estimation of aquifer transmissivity from dar zarrouk parameters in porous media. Hydrology 50:393-399

Obiajulu OO, Okpoko EI (2015) Geoelectric investigation of groundwater potential of Ihiala and its environ, Anambra State Nigeria. IOSR J Appl Geol Geophys 3(6):14-20

Obiora DN, Ajala AE, Ibuot JC (2015) Evaluation of aquifer protective capacity of overburden unit and soil corrosivity in Makurdi,
Benue state, Nigeria, using electrical resistivity method. J Earth Syst Sci 124(1):125-135

Obiora DN, Ibuot JC, George NJ (2016a) Evaluation of aquifer potential, geoelectric and hydraulic parameters in Ezza North, Southeastern Nigeria, using geoelectric sounding. Int J Environ Sci Technol 13:435-444

Obiora DN, Ibuot JC, George NJ, Offiah SU (2016b) Delineation of groundwater saturation indicators and their distributions in the complex argillaceous geological units of Ezza north local government area of Ebonyi state Nigeria. Curr Sci 10(4):701-708

Obiora DN, Alhassan UD, Ibuot JC, Okeke FN (2016c) Geoelectric evaluation of aquifer potential and vulnerability of northern Paiko, Niger State, Nigeria. Water Environ Res 88(7):644-651

Odumodu OI, Ekenta EO (2012) Modelling operation and maintenance management of water supply in Awka, Anambra State, Nigeria. J Emerg Trends Eng Appl Sci 3(5):868-873

Offodile ME (1983) The occurrence and exploitation of groundwater in nigeria basement complex. J Min Geol 20:131-146

Oladapo MI, Mohammed MZ, Adeoye OO, Adetola OO (2004) Geoelectric investigation of the ondo-state housing corporation Estate Ijapo akure southwestern Nigeria. J Min Geol 40(1):41-48

Reyment RA (1965) Aspects of geology of Nigeria. University of Ibadan Press, Ibadan

Simpson A (1949) The lignite seams of Asaba Division, Benin Province. Annual Report of Geological Survey of Nigeria, p 6-14

Villumsen A, Sonderskov C (1982) Vulnerability maps: a promising tool in groundwater protection. Aqua 5:466-468

Wilson RC (1925) The geology of the eastern railway: section i, portharcourt to enugu. brown coal in Nigeria. Bull Geol Surv Nigeria 8:13-86

Wilson RC, Bain AD (1928) The Nigerian coalfield section ii, parts of onitsha and Owerri Provinces. Bull Geol Surv Nigeria 12:12-50

Publisher's Note Springer Nature remains neutral with regard to jurisdictional claims in published maps and institutional affiliations. 